\title{
Andrzej Orczykowski
}

\section{Kanoniczne problemy w Orędziach Ojca Świętego Jana Pawła II na Światowy Dzień Migranta}

Prawo Kanoniczne : kwartalnik prawno-historyczny 49/1-2, 235-268

2006

Artykuł został opracowany do udostępnienia w internecie przez Muzeum Historii Polski w ramach prac podejmowanych na rzecz zapewnienia otwartego, powszechnego i trwałego dostępu do polskiego dorobku naukowego i kulturalnego. Artykuł jest umieszczony w kolekcji cyfrowej bazhum.muzhp.pl, gromadzącej zawartość polskich czasopism humanistycznych i społecznych.

Tekst jest udostępniony do wykorzystania w ramach dozwolonego użytku. 
Prawo Kanoniczne

$49(2006) \mathrm{nr} 1-2$

KS. ANDRZEJ ORCZYKOWSKI SCHR

Uniwersytet Kardynała Stefana Wyszyńskiego w Warszawie

\section{KANONICZNE PROBLEMY W ORĘDZIACH OJCA ŚWIĘTEGO JANA PAWŁA II NA ŚWIATOWY DZIEŃ MIGRANTA}

Treść: Wstęp; 1. Przynależność migrantów do Kościoła powszechnego; 2. Udział migrantów w życiu Kościoła partykularnego; 3 . Duszpasterstwo migrantów zadaniem Kościoła; 4. Ochrona praw migrantów; Zakończenie

\section{Wstęp}

Zjawisko współczesnej migracji niesie ze sobą nie tylko problemy natury socjalnej, ekonomicznej, kulturalnej czy politycznej, ale również religijnej i pastoralnej. Bardzo żywe zainteresowanie tym zjawiskiem okazuje Kościól, o czym świadczą między innymi liczne dokumenty Stolicy Apostolskiej ${ }^{1}$. Kościół jest zainteresowany przede wszystkim religijną stroną migracji i problemami wszechstronnej opieki nad migrantami. W ramach prawnie określonej i faktycznie zorganizowanej opieki duszpasterskiej nad migrantami ustanowiono w Kościele, między innymi „Dzień Migranta” (Dies migratoris)².

Genezy Dnia Migranta należy szukać w diecezjach włoskich, gdzie tamtejsi biskupi wyznaczali dzień, w którym zbierano ofiary

\footnotetext{
${ }^{1}$ Ostatnio zostały opracowane dwa zbiory dokumentów Kościoła dotyczących zjawiska migracji: zob. G. T a s s e 11 o, L. F a v e r o, Chiesa e mobilità umana. Documenti della Santa Sede dal 1883 al 1983, Roma 1985; F on d a z i o n e Mig r a n t e s de 11 a Confere $\mathrm{nz}$ a E p is c o p le I t a 1 i a n a, Enchiridion della Chiesa per le Migrazioni. Documenti magisteriali ed ecumenici sulla pastorale della mobilità umana (18872000), a cura di Giovanni Graziano Tassello con la collaborazione di Luisa Deponti e Mariella Guidotti, Edizioni Dehoniano Bologna 2001.

${ }^{2}$ Pontificio Consiglio della Pastorale per i Migranti e gli I t i n e r a $\mathrm{n} \mathrm{i}$, Istruzione ,Erga migrantes caritas Christi" (La carità di Cristo verso $\mathrm{i}$ migranti) (03.05.2004) (odtąd: EMCC), Città del Vaticano 2004, nn. 29, 72; wersje w językach używanych przez Stolicę Apostolską w „People on the Move” 36 (2004) n. 95.
} 
na rzecz pomocy dla masowo emigrujących rodaków do obu Ameryk i niektórych krajów Europy. Od 1914 roku na życzenie papieża Benedykta XV we Włoszech obchodzono „Dzień Emigranta Włoskiego" . Z upływem czasu "Dzień Emigranta” zwany inaczej „Dzień Migranta” lub „Dniem Migracji” zaczęto obchodzić także w innych krajach ${ }^{4}$, w tym również w Polsces. W „Wielkiej Karcie Migrantów” - jak określa się konstytucję apostolską „Exul familia” - podkreślono znaczenie troski Kościoła o emigrantów i stworzenie właściwego stosunku wiernych do zjawiska migracji oraz ukazywanie duchowych niebezpieczeństw i problemów z nim związanych ${ }^{6}$. W dziele opieki nad emigrantami pomocnym ma być między innymi: „Dzień Emigranta” przeżywany w całym Kościele? . „Dzień Migranta" obchodzony w takim czasie i taki sposób, jak to doradzają miejscowe warunki i postulaty społeczności świeckiej - ma na celu zwrócenie uwagi na aktualne problemy migrantów oraz budzenie poczucia odpowiedzialności za duchową i materialną pomoc dla "ludzi w drodze".

Jan Paweł II w poszczególnych latach swojego pontyfikatu kierował do całego Kościoła i świata orędzia na Światowy Dzień Migranta, w których podejmował aktualne tematy dotyczące zjawiska migracji. Mając na uwadze, że celem opracowania jest ukazanie kano-

${ }^{3} \mathrm{~S}$ a c r a Congre gat i o Cons is t o $\mathrm{r}$ i a 1 is, Litterae circulares ad R. mos Ordinarius Dioecesum Italiae, de spinituali emigrantium cura (6.12.1914), "Acta Apostolicae Sedis. Commentarium officiale" (odtad: AAS) 6 (1914), 699-701.

${ }^{4} \mathrm{~S}$ a c ra Cong re g a t i o Con $\mathrm{s}$ is t o r i a lis, Litterae circulares ad R. mos Amenicae Ordinarios, de emigrantium Italonum cura (22.02.1915), AAS 7 (1915), 145-146.

${ }^{5}$ W Polsce na polecenie kard. Augusta Hlonda w dniach 9-15 czerwca 1930 r. obchodzono "Tydzień Emigranta Polaka”, który później obchodzono jako „Dzień Opieki nad Polakami na Obczyźnie” [zob. „Miesięcznik Kościelny” 45 (1930) nr 6, ss. 66-67]. Natomiast od 1937 roku obchodzono „Dzień Polaka z Zagranicy”. Od tego czasu była to coroczna uroczystość o charakterze religijnym i narodowym mająca na celu budzenie u wiernych poczucie odpowiedzialności za duchową i materialną pomoc dla migrantów i ich duszpasterzy oraz rozwijanie ducha braterstwa między różnymi grupami etnicznym [zob. Dzień Polaka za Granica, „Głos Seminarium Zagranicznego” 5 (1937) nr 1, s. 5].

"P i u s XII, Constitutio Apostolica de spirituali emigrantium cura "Exul Familia" (1.08.1952) (odtad: EF), AAS 44 (1952), 649-704, 45-47.

${ }^{7}$ W EF zapisano dyspozycje dotyczace organizowania „Dnia Emigranta Wloskiego" (nn. $48,49 \S 1,50$ ) oraz odpowiednio do emigrantów innych narodowości czy języków „Dnia Emigranta” (n. 49 § 2).

${ }^{8} \mathrm{~S}$ a c r a Cong r e g a t i o pro E p is c o p i s, Instructio „De pastorali migratonum cura” (22.08.1969), AAS 61 (1969), 614-643, n. 24 § 5-6; EMCC, art. 21. 
nicznych problemów przedstawionych w orędziach - a nie stworzenie ich katalogu - zauważymy w jaki sposób zjawisko migracji obecne w społeczności kościelnej akomoduje się w jej prawodawstwie.

Wśród kanonicznych problemów migracji poruszonych przez Jana Pawła II na czoło wysuwają się kwestie: 1) przynależności migrantów do wspólnoty Kościoła powszechnego, 2) udziału migrantów w życiu Kościoła partykularnego, 3) duszpasterstwa migrantów, 4) ochrony praw migrantów.

\section{Przynależność migrantów do Kościoła powszechnego}

W orędziach Jana Pawła II w temacie przynależności migrantów do Kościola powszechnego na czoło wysuwają się kwestie: wiary w Jezusa Chrystusa i chrztu w imię Trójcy Świętej, troski Najwyższej Władzy Kościelnej o migrantów, obecności i dialogu Kościoła z migrantami w środowiskach wielokulturowych i wieloreligijnych.

\subsection{Wiara w Jezusa Chrystusa i chrzest}

w imię Trójcy Świętej fundamentem przynależności do Kościoła

Jan Paweł II z naciskiem podkreśla, że o przynależności do wspólnoty katolickiej nie decyduje narodowość ani pochodzenie spoleczne czy etniczne, ale wiara w Jezusa Chrystusa i chrzest w imię Trójcy Świętej. Ten „kosmopolityczny” charakter Ludu Bożego jest widoczny praktycznie we wszystkich Kościołach partykularnych, ponieważ migracje przekształciły nawet niewielkie i dawniej odosobnione wspólnoty w społeczności pluralistyczne i wielokulturowe. Miejsca, w których jeszcze do niedawna rzadko gościli obcokrajowcy, stały się domem dla ludzi z różnych części świata. Coraz częśsiej podczas niedzielnej Eucharystii Ewangelia odczytywana jest w językach, których wierni nigdy przedtem nie słyszeli. Te wspólnoty mają, zatem nowe możliwości doświadczenia powszechności Kościola, cechy która wyraża jego zasadniczą otwartość na wszystko, co jest dziełem Ducha w każdym narodzie. Kościół zdaje sobie sprawę, że uzależnianie przynależności do lokalnej wspólnoty od kryteriów etnicznych lub innych znamion zewnętrznych prowadziłoby do zubożenia wszystkich, byłoby też sprzeczne z podstawowym prawem ochrzczonych do sprawowania kultu i udziału w życiu wspólnoty. Co więcej, jeśli nowi przybysze czują się niemile widziani w lokalnej wspólnocie parafialnej, ponieważ nie znają miejscowego języka i nie stosują się do miejscowych obyczajów, łatwo stają 
się „Zagubionymi owcami”. Niebezpieczeństwo utraty tych „maluczkich" z powodu dyskryminacji - choćby tylko ukrytej - powinno budzić głęboką troskę zarówno duszpasterzy, jak i wiernych². Zatem według Jana Pawła II wyrazem katolickości jest nie tylko braterska wspólnota ochrzczonych, ale także gościnność okazana cudzoziemcowi niezależnie od wyznawanej przez niego religii, odrzucenie wszelkich barier i dyskryminacji rasowej oraz uznanie osobowej godności każdego człowieka, czemu winna towarzyszyć aktywna obrona jego niezbywalnych praw ${ }^{10}$.

Działalność Kościola na rzecz migrantów i uchodźców nie może polegać jedynie na tworzeniu struktur zapewniających im gościnne przyjęcie i solidarną pomoc. Taka postawa umniejszałaby bogactwo powołania Kościoła, który ma przede wszystkim przekazywać wiarę. Pilna potrzeba niesienia pomocy migrantom w trudnych sytuacjach, w jakich się często znajdują, nie powinna jednak wstrzymywać gloszenia prawd ostatecznych, na których opiera się chrześcijańska świadomośćc ${ }^{11}$.

Papież przypomina dobrze znaną zasadę, że w Kościele nikt nie jest obcy, a Kościół nie jest obcy dla żadnego człowieka w żadnym miejscu. Kościól - jako sakrament jedności, a zatem znak i moc zespalająca cały rodzaj ludzki - jest miejscem, gdzie również nielegalni imigranci zostają rozpoznani i przyjęci jak siostry i bracia ${ }^{12}$. Jan Paweł II zwraca się również z naglącym apelem do chrześcijańskich społeczności o serdeczną i braterską gościnność, potwierdzającą, bardziej czynami niż słowami, że ,rodziny emigrantów powinny znaleźć wszędzie w Kościele swoją ojczyznę." To zadanie leży w samej naturze Kościola, który jest znakiem jedności w różnorodności ${ }^{13}$. Ojciec Święty apeluje, aby chrześcijańska wspólnota, dzięki duchowi gościnności, który powinien ją ożywiać, pozwoliła migrantom w konkretny sposób odczuć, że nikt nie jest pozbawiony rodziny na

${ }^{9} \mathrm{~J}$ o a $\mathrm{n} \mathrm{n}$ e s $\mathrm{P}$ a u 1 u s II, Ob diem migratoribus et profugis dictum (odtąd: 24.10.2002), AAS 95 (2003), 336-339, 2.

${ }^{10} \mathrm{G}$ i o v a n $\mathrm{n}$ i $\mathrm{P}$ a o $10 \mathrm{II}$, Il giubileo porta il credente ad aprirsi allo straniero. Messaggio per la giornata mondiale del migrante (odtąd: 2.02.1999) „Quaderno di Servizio Migranti" (odtąd: QSM) 27, 149-154,6.

${ }_{11}^{\mathrm{J}}$ o a $\mathrm{n} \mathrm{n}$ e s P a u 1 u s II, Ob diem migrantibus dictum missus (odtąd: 21.08.1996), AAS 89 (1997), 136-141, 3.

${ }^{12} 21.08 .1996,5$.

${ }^{13} \mathrm{~J}$ o a $\mathrm{n}$ n e s P a u 1 u s II, Ob diem Migrantibus dicatum missus (odtąd: 10.08.1994), AAS 87 (1995), 277-281, 5. 
tym świecie, bowiem Kościół jest domem i rodziną dla wszystkich, a szczególnie dla „utrudzonych i obciążonych" ${ }^{14}$.

Powołaniem Kościoła jest okazywanie gościnności migrantom i służenie im szczególnie w trudnych dla nich sytuacjach: wykorzenienia, niewrażliwości otoczenia na ich problemy i spychania ich na margines społeczeństwa. Właśnie, dlatego Kościól powinien działać intensywniej, być bardziej czujny, rozumnie i z wyczuciem wprowadzać w życie wszystkie stosowne inicjatywy, aby sprzeciwić się tej tendencji i uniknąć wynikających z niej zagrożeń. Jego niezmiennym zadaniem jest przyczynianie się do usuwania wszelkich przeszkód, które ludzki egoizm stawia na drodze najsłabszych ${ }^{15}$.

Zbieżność problematyki migracyjnej z powołaniem Kościoła może, więc być bodźcem do zastanowienia się nad specyficznym wkładem w rozszerzanie Królestwa Bożego, do wniesienia którego powołani są migranci właśnie ze względu na specyficzną sytuację, w jakiej się znajdują. Biskup Rzymski, Jan Paweł II zapewnia migrantów, że Kościól jest z nimi oraz pragnie ich otoczyć opieką i wsparciem, jakich potrzebują ${ }^{16}$.

\subsection{Troska Najwyższej Władzy Kościelnej o migrantów}

Biskup Rzymski - posiadając na mocy swego urzędu nad całym Kościołem oraz nad wszystkimi Kościołami partykularnymi oraz ich zespołami naczelną władzę zwyczajną, przez którą zostaje jednocześnie potwierdzona i umocniona władza własna, zwyczajna i bezpośrednia, jaką posiadają biskupi w kościołach partykularnych powierzonych ich pieczy ${ }^{17}$ - otacza swoją troską również migrantów. W wykonywaniu tego zadania, Biskupowi Rzymskiemu świadczą pomoc: biskupi - którzy mogą to czynić w różny sposób, w tym także poprzez Synod Biskupów; kardynałowie, a także inne osoby oraz różne instytucje stosownie do aktualnych potrzeb. Wszystkie te osoby i instytucje, w imieniu i jego władzą wykonują powierzone

\footnotetext{
${ }^{14} \mathrm{~J}$ o a $\mathrm{n}$ n e s P a u 1 u s II, Ob diem Migrantibus dicatum missus (odtad: 31.07.1992), AAS 85 (1993), 425-428, 6.

${ }^{15} \mathrm{~J}$ o a n n e s P a u 1 u s II, Ob diem Migrantibus dicatum missus (odtąd: 25.07.1990), AAS 83 (1991), 203-208, 8.

${ }^{16} 10.08 .1994,5$.

${ }^{17}$ Codex Iuris Canonici auctoritatae Joannis Pauli PP II promulgatus (25.01.1983) (odtąd: CIC), AAS 75 (1983), pars II, 1-318, $333-\S 1$.
} 
sobie zadanie dla dobra wszystkich Kościołów, zgodnie z normami określonymi w prawie ${ }^{18}$.

Jedną z instytucji wspierających Biskupa Rzymskiego oraz Kolegium Biskupów w działaniu na rzecz migrantów jest Papieska Rada Duszpasterstwa Migrantów i Podróżnych. Jej instytucjonalnym zadaniem - pełnionym w imieniu Kościoła - jest opieka nad wszystkimi kategoriami ludzi będących w drodze, bowiem obecnie termin: „migranci” ma bardzo szerokie znaczenie i stosuje się go przede wszystkim do uchodźców i wygnańców, poszukujących wolności i bezpieczeństwa poza granicami swoich krajów rodzinnych, ale także do młodzieży studiującej za granicą oraz tych, którzy opuszczają swoje kraje, aby gdzie indziej znaleźć lepsze warunki życia. Zjawisko migracji nieustannie się rozszerza, co zmusza kościelną wspólnotę do refleksji i stanowi wyzwanie dla jej duszpasterstwa. Jan Paweł II przypomina, że już Sobór Watykański II w dekrecie "Christus Dominus" (nr 18) wzywa, aby "specjalną troską otoczyć tych wiernych, którzy ze względu na warunki życia nie mogą dostatecznie korzystać z ogólnej zwykłej opieki duszpasterskiej proboszczów lub całkowicie są jej pozbawieni, jak np. mnogie rzesze emigrantów, uchodźcy i wygnańcy"19.

Wśród inicjatyw Kościola mających na celu przyjście z pomocą migrantom Jan Paweł II przypomina również o dzialalności Międzynarodowej Komisji Katolickiej ds. Migracji. Powstała ona w 1951 r., z inicjatywy ówczesnego substytuta Sekretariatu Stanu, abpa Giovanniego Battisty Montiniego. Miała odpowiadać na potrzeby związane z ruchami migracyjnymi, wywołanymi przez konieczność odtworzenia struktur produkcyjnych zniszczonych podczas wojny, a także przez dramatyczną sytuację, w jakiej znalazły się całe społeczności, zmuszone do przesiedlenia się w związku z nowym układem geopolitycznym, narzuconym przez zwycięzców. Przeszło 50letnia historia tego stowarzyszenia oraz jego przekształcenia, które pozwalały mu dostosowywać się jak najlepiej do zmieniających się sytuacji, są świadectwem jego wielostronnej, rozumnej i konkretnej działalności. Przemawiając na inauguracyjnym posiedzeniu w dniu 5 czerwca 1951 r., przyszły papież Paweł VI podkreślił, że należy usu-

${ }^{18} \mathrm{CIC}, 334$

${ }^{19} \mathrm{~J}$ o a $\mathrm{n} \mathrm{n}$ e s $\mathrm{P}$ a u $1 \mathrm{u}$ s II, Ob diem migratoribus et itinerantibus dicatum (odtąd: 2.02.2001), AAS 93 (2001), 377-384, 1. 
wać przeszkody utrudniające migracje, aby dać możliwość znalezienia pracy bezrobotnym i schronienie bezdomnym; dodał też, że sprawa, której miała służyć nowo powstała Międzynarodowa Komisja ds. Migracji, jest sprawą samego Chrystusa. Jan Paweł potwierdza, że słowa te i dzisiaj zachowują w pełni swą aktualność. Papież dziękując Bogu za działalność Komisji zlecil jej, aby nadal śledziła z uwagą sytuację uchodźców i migrantów i niosła im pomoc z tym większą energią i gorliwością, im poważniejsze są trudności i zagrożenia, z jakimi zmaga się ta grupa osób ${ }^{20}$.

\subsection{Obecność Kościoła i dialog z migrantami}

w środowiskach wielokulturowych i wieloreligijnych

Kościół, pełniąc wiernie swoje zadanie w służbie Ewangelii, nieustannie stara się docierać do ludzi wszystkich narodowości, aby nieść im radosną nowinę zbawienia ${ }^{21}$. Jeżeli - mimo odmienności istnieje wspólna wola dialogu, można znaleźć obszary twórczej wymiany i rozwijać więzi owocnej przyjaźni, która z kolei może prowadzić do skutecznej współpracy w realizowaniu wspólnych celów i służyć wspólnemu dobru. Jest to opatrznościowa szansa, zwłaszcza dla wielkich miast, gdzie bardzo wysoka jest liczba imigrantów reprezentujących różne kultury i religie. Można by w tym wypadku mówić nawet o prawdziwych "laboratoriach" cywilizowanego współistnienia i konstruktywnego dialogu. Chrześcijanin, kierując się miłością do swego Boskiego Mistrza, który przez śmierć na krzyżu odkupił wszystkich ludzi, sam otwiera ramiona i serce dla wszystkich. Jego postawa winna wyrażać głęboką kulturę szacunku i solidarności, zwłaszcza jeśli żyje on w środowiskach wielokulturowych i wieloreligijnych ${ }^{22}$. Chrześcijanie świadomi transcendentnego działania Ducha dostrzegają w różnych kulturach cenne elementy religijne i ludzkie, które mogą stanowić dobrą podstawę dla wzajemnego porozumienia. Jan Paweł II zauważa, że trzeba połączyć zasadę poszanowania odmienności kulturowych z ochroną wspólnych wartości, z których nie wolno rezygnować, gdyż ich fundamen-

${ }^{20} 2.02 .2001,7$.

${ }^{21} 2.02 .2001,1$.

${ }^{22} \mathrm{~J}$ e a $\mathrm{n} \mathrm{P}$ a u 1 II, Message de Sa Sainteté le Pape Jean Paul II pour la LXXXVIII Journée Mondiale du Migrant et du Réfugié (2002) (odtąd: 25.07.2001), „People on the Move" 34 (2001) n. 87, pp. 5-8, 3. 
tem są uniwersalne prawa człowieka. W ten właśnie sposób tworzy się klimat obywatelskiej mądrości, który pozwala na pokojowe wspólistnienie ${ }^{23}$.

Tak, więc, skoro dialog międzyreligijny stanowi jedno $z$ najważniejszych wyzwań naszej epoki, zjawisko migracji może sprzyjać jego rozwojowi. Rzecz jasna, dialog ten - jak napisał Jan Paweł II w Liście apostolskim „Novo millennio ineunte” (nr 56) - „nie może się (...) opierać na obojętności religijnej”. Przeciwnie, chrześcijanie mają obowiązek prowadzić go składając pełne świadectwo o nadziei. Jednak dialog nie może ukrywać daru wiary, ale winien ukazywać go w pełnym świetle. Daru wiary nie można zachowywać tylko dla siebie. Stykając się z migrantami i obcokrajowcami - wyznawcami innych religii - chrześcijanie mają się dzielić z innymi okazując oczywiście najwyższy szacunek dla ich odmiennych sposobów myślenia - skarbem wiary. Aby wypelnić tę misję, trzeba poddać się prowadzeniu Ducha Swiętego. W dniu Pięćdziesiątnicy to Duch Prawdy urzeczywistnił do końca Boży zamysł jedności rodzaju ludzkiego w wielości jego kultur i religii. Słuchając apostołów, liczni pielgrzymi zgromadzeni w Jerozolimie wołali zdumieni: „słyszymy ich głoszących w naszych językach wielkie dzieła Boże" (Dz 2, 11). Od tamtego dnia Kościół pełni swą misję, głosząc ,wielkie dziela”, jakich Bóg nieustannie dokonuje pośród ludzi różnych ras, ludów i narodów ${ }^{24}$.

Historia pokazuje, że tam, gdzie katolicy osiedlający się w innych krajach byli otoczeni opieką duszpasterską, nie tylko zachowali wiarę, ale znaleźli też podatny grunt, aby ją pogłębiać, przeżywać bardziej osobiście i świadczyć o niej własnym życiem. W ciągu stuleci migracje były zawsze nośnikiem ewangelicznego orędzia w nowych regionach świata. Dzisiaj obraz migracji zmienia się radykalnie: $z$ jednej strony zmniejsza się liczba migrantów katolickich, z drugiej zaś coraz więcej jest migrantów niechrześcijańskich, którzy osiedlają się w krajach o większości katolickiej. Jan Paweł II przypomina zadania Kościoła wobec migrantów niechrześcijańskich, podkreślając, że przez swoje osiedlenie się stwarzają oni nowe okazje do kontaktów i wymiany kulturowej, które winny pobu-

${ }^{23} \mathrm{~J}$ o a $\mathrm{n} \mathrm{n}$ e s $\mathrm{P}$ a u $1 \mathrm{u}$ s II, Ob Diem in universo orbe migrantibus et profugis dicatum in annum 2005 (odtąd: 24.11.2004), AAS, 97 (2005), 173-175, 3.

${ }^{24} 25.07 .2001,4$. 
dzać chrześcijańską społeczność do okazania gościnności, gotowości do dialogu, pomocy i braterstwa. Wymaga to żywszego uświadomienia sobie znaczenia katolickiego nauczania o religiach niechrześcijańskich, aby można było prowadzić głęboki, wytrwały i nacechowany szacunkiem dialog międzyreligijny, prowadzący do wzajemnego poznania i wzbogacenia. W świetle ekonomii zbawienia Kościół nie widzi sprzeczności między głoszeniem Chrystusa a dialogiem międzyreligijnym, odczuwa jednak potrzebę godzenia ich w obrębie misji ,ad gentes”. Trzeba bowiem, aby oba te elementy zachowywały swą ścisłą więź i zarazem swą odrębność, zatem nie należy ich mieszać ani nimi manipulować, ani uważać ich za równoważne, tak jakby były zamienne ${ }^{25}$.

Nowym wyzwaniem dla Kościoła - według Jana Pawła II - jest obecność niechrześcijańskich imigrantów w krajach o dawnej tradycji chrześcijańskiej. Zjawisko to nieustannie wzbudza w Kościele dzieła miłosierdzia, którego wyrazem jest gościnność i pomoc okazywana braciom i siostrom poszukującym pracy i mieszkania. Jest to w pewien sposób działalność całkiem podobna do tej, jaką prowadzi wielu misjonarzy w krajach misyjnych, zajmując się chorymi, ubogimi, analfabetami. Taki właśnie jest styl działania ucznia Chrystusa: wychodzić naprzeciw oczekiwaniom i potrzebom bliźnich cierpiących niedostatek. Podstawowym celem jego misji jest jednak gloszenie Chrystusa i Jego Ewangelii. Kościół wie, że głoszenie Jezusa jest pierwszym aktem miłosierdzia wobec człowieka, przewyższającym jakikolwiek gest wielkodusznej nawet solidarności. Czasem, w środowisku zdominowanym przez coraz powszechniejszą obojętność i relatywizm religijny, duchowy wymiar posługi charytatywnej nie jest zbyt wyraźnie widoczny. U niektórych dochodzi też do głosu obawa, że związanie dzieł miłosierdzia z ewangelizacją może narazić na zarzut prozelityzmu. Głoszenie Ewangelii miłosierdzia i dawanie o niej świadectwa jest „tkanką łączną" misji prowadzonej wśród migrantów ${ }^{26}$.

Głoszenie Ewangelii miłości w rozległym i zróżnicowanym świecie migrantów wymaga poświęcenia szczególnej uwagi sferze kultury. Dla wielu migrantów przybycie do obcego kraju oznacza zetknięcie się z nieznanymi im sposobami życia i myślenia, które wywołują w nich różne reakcje. Miasta i kraje zamieszkiwane są w co-

\footnotetext{
${ }^{25} 2.02 .2001,6$

${ }^{26} 2.02 .2001,7$.
} 
raz większej mierze przez społeczności wieloetniczne i wielokulturowe. Jest to wielkim wyzwaniem także dla chrześcijan. Obiektywna analiza tej nowej sytuacji pozwala dostrzec wiele wartości zasługujących na najwyższe uznanie. Duch Święty nie jest ograniczony w swym działaniu przez podziały etniczne i kulturowe, lecz inspiruje i oświeca ludzi na wiele tajemniczych sposobów. Różnymi drogami przybliża wszystkich do zbawienia, do Jezusa, wcielonego Słowa, który jest spełnieniem pragnień wszystkich religii świata i dlatego jest ich jedyną i ostateczną przystanią. Taka analiza z pewnością pomoże migrantowi niechrześcijańskiemu dostrzec we własnej religijności silny element tożsamości kulturowej, a zarazem może go też uzdolnić do odkrycia wartości wiary chrześcijańskiej. W tym względzie niezwykle użyteczna może być współpraca Kościołów lokalnych i misjonarzy znających kulturę imigrantów. Należy tworzyć więzi między spolecznościami migrantów a ich krajami rodzinnymi, szerząc zarazem w ich nowych spoleczeństwach, do których przybywają, wiedzę o kulturach i religiach imigrantów oraz o motywach, które skłoniły ich do opuszczenia ojczyzny. Ważne jest, aby dopomagać społecznościom goszczącym migrantów nie tylko w okazywaniu miłosierdzia i gościnności, ale także w otwarciu się na spotkanie, na wspólpracę i dialog; trzeba też umożliwiać pobyt duszpasterzom, którzy przybywają z rodzinnych krajów migrantów do ich nowych miejsc osiedlenia, aby mogli pracować wśród swoich rodaków. Bardzo pożyteczne byłoby tworzenie dla nich specjalnych ośrodków, które przygotowywałyby ich do nowych zadann ${ }^{27}$.

Jan Paweł II zauważa, że nowym zjawiskiem związanym z migracją jest rozwój organizacji o charakterze międzynarodowym i instytucji kulturalnych, które ofiarują zwłaszcza ludziom młodym, możliwość wyboru różnych dróg formacji na uniwersytetach wielu krajow. Temu wzrostowi migracji Kościół przygląda się życzliwie nie tylko, dlatego że dostrzega w niej obraz samego siebie - ludu pielgrzymujaccego - ale przede wszystkim, dlatego że widzi w niej wielką szansę zjednoczenia różnorakich kultur i umocnienia powszechnego braterstwa ${ }^{28}$.

${ }^{27} 2.02 .2001,8$.

${ }^{28} \mathrm{G}$ i o v a $\mathrm{n} \mathrm{n}$ i $\mathrm{P}$ a o 1 o II, Le migrazioni presentano un duplice volto, quello della diversità e quello dell universalità. Messaggio per la giornata mondiale del migrante (odtad: 21.08.1991), QSM 15, 41-44, 2. 


\section{Udział migrantów w życiu Kościoła partykularnego}

Wśród problemów migracji pojawiających się w życiu Kościoła partykularnego Jan Paweł II w szczególny sposób zauważa: konieczność troski diecezji o przebywających poza granicami własnej ojczyzny i własnej wspólnoty etnicznej oraz obecność migrantów w parafii.

\subsection{Troska diecezji o przebywających poza granicami własnej ojczyzny i własnej wspólnoty etnicznej}

Jan Paweł II podkreśla, że poszczególne Kościoły partykularne wiedzą, że spoczywa na nich obowiązek należytej troski o tych wszystkich, którzy z jakiegokolwiek powodu są zmuszeni do przebywania poza granicami swojej ojczyzny i własnej wspólnoty etnicznej. Celem tej troski jest włączenie ich w życie Kościoła, z pełnym poszanowaniem ich prawa do wolności ${ }^{29}$.

Papież zachęca również migrantów i uchodźców, aby nie zamykali się w sobie i nie izolowali od życia duszpasterskiego diecezji i parafii, która ich przyjęła. Zarazem jednak przestrzega duchowieństwo i wiernych, by nie próbowali emigrantów po prostu asymilować, likwidując ich odrębność. Kościół stara się raczej włączać tych braci stopniowo do swojej wspólnoty, uznając wartość ich odmienności, aby budować prawdziwą wspólnotę wierzących, gościnną i solidarną $a^{30}$. Wskazane jest, aby wspólnoty przyjmujące migrantów i uchodźców tworzyły dla nich struktury, które pozwolą im faktycznie podjąć odpowiedzialność, jaka na nich spoczywa. W tej perspektywie kapłan, któremu bezpośrednio powierzono opiekę nad imigrantami, powinien stawać się pomostem między różnymi kulturami i mentalnościami. Wymaga to, by miał on świadomość, że pełni posługę naprawdę misyjną - w taki sam sposób - w jaki Chrystus włączył się przez swoje wcielenie w społeczne i kulturalne warunki ludzi, wśród których przebywal. Również fakt, że prace apostolskie na rzecz migrantów spotykają się czasem z nieufnością czy wręcz wrogością otoczenia, misjonarz migrantów nie powinien w żadnym

\footnotetext{
${ }^{29} \mathrm{~J}$ o a $\mathrm{n} \mathrm{n}$ e s $\mathrm{P}$ a u 1 u s II, Ob diem in universa Ecclesia migrantibus dicatum missus (odtad: 16.07.1985), AAS 77 (1985), 1161-1165, 2.

${ }^{30} \mathrm{G}$ i o v a n $\mathrm{n}$ i $\mathrm{P}$ a o 1 o II, Sia rispettata ogni persona e siano bandite le discriminazioni che umiliano la dignità umana. Messaggio per la giornata mondiale del migrante (odtąd: 9.11.1997), QSM 27, 144-148, 3.
} 
przypadku rezygnować $\mathrm{z}$ tego dzieła solidarności, służącego postępowi człowieka. Nakaz zawarty w słowach Jezusa: „byłem przybyszem, a przyjęliście Mnie" (Mt 25, 35), pozostaje całkowicie w mocy w każdych okolicznościach $i$ jest wyzwaniem dla sumienia wszystkich, którzy chcą iść Jego śladami. Dla człowieka wierzącego przyjęcie bliźniego nie jest jedynie gestem filantropii czy zwykłej ludzkiej życzliwości dla innych. Jest czymś znacznie więcej, bo w każdym człowieku chrześcijanin potrafi dostrzec Chrystusa, który pragnie, byśmy kochali Go i służyli $\mathrm{Mu}$ w braciach, zwłaszcza w najuboższych i najbardziej potrzebujących ${ }^{31}$.

Mając na uwadze potrzebę tworzenia struktur opieki nad emigrantami w diecezji Jan Paweł II przypomina postać Jan Scalabriniego, który z bezpośredniego doświadczenia dramatu emigrantów, bardzo wyraźnie dostrzegal potrzebę zapewnienia im specjalnej opieki duszpasterskiej poprzez sieć instytucji pomocy społecznej. W tym celu założył Zgromadzenia Misjonarzy i Misjonarek św. Karola, dając dowód niezwykłej intuicji duchowej i zmysłu praktycznego. Bardzo stanowczo domagał się też wprowadzenia odpowiedniego prawodawstwa i powołania instytucji, które miały zapewnić opiekę humanitarną i ochronę prawną migrantów przed wszelkimi formami wyzysku. Dzisiaj, choć kontekst społeczny jest z pewnością inny, duchowi synowie i córki biskupa Scalabriniego, do których przyłączyły się później - jako spadkobierczynie tego samego charyzmatu - Swieckie Misjonarki Skalabriniańskie, idą dalej tą drogą, dając świadectwo miłości Chrystusa do migrantów i głosząc im Ewangelię, uniwersalne orędzie zbawienia ${ }^{32}$.

Jan Paweł II wzywa Kościoły partykularne, aby pobudzały do refleksji, by udzielały wskazań i dostarczały informacji, a przez to pomagały osobom zaangażowanym na polu duszpasterskim i socjalnym w roztropnym działaniu w tej jakże delikatnej i złożonej dziedzinie $^{33}$. Zadaniem diecezji jest mobilizacja sil, aby ludzie zmuszeni żyć poza systemem ochronnym społeczności cywilnej, odnaleźli poczucie braterstwa we wspólnocie chrześcijańskiej ${ }^{34}$. Ojciec Święty

$319.11 .1997,3$.

${ }^{32} 9.11 .1997,5$

${ }^{33} \mathrm{G}$ i o v a n n i P a o 1 o II, La condizione di irregolarita legale non consente sconti sulla dignità del migrante. Messaggio per la giomata mondiale del migrante (odtad: 25.07.1995), QSM 15, 57-60, 5.

34 25.07.1995, 5 . 
zwraca się do biskupów, aby dbali o tworzenie wspólnot etnicznych lub językowych, ustanawiając parafie personalne lub misje duszpasterskie wszędzie tam, gdzie ich zdaniem może to być pożyteczne lub wskazane ze względów duszpasterskich ${ }^{35}$.

Wszystkie Kościoły lokalne winny obchodzić Światowy Dzień Migranta - w jedną z niedziel roku, wyznaczoną przez krajową Konferencję Episkopatu - jako sposobność do refleksji nad tymi problemami, aby uświadomić sobie ich najbardziej dramatyczne aspekty, budzić społeczną wrażliwość i skłaniać do solidarności $\mathrm{z}$ migrantami ${ }^{36}$. Jan Paweł II stwierdza, że dzięki migracjom Kościoly lokalne miały często sposobność potwierdzić i umocnić swą katolickość, przyjmując gościnnie różne narodowości, a przede wszystkim łącząc je w jedną społeczność. Źródłem jedności Kościoła nie jest wspólne pochodzenie jego członków, ale Duch Pięćdziesiątnicy, On bowiem z wszystkich narodów czyni nowy lud, którego celem jest Królestwo, udziałem wolność synów Bożych, a prawem przykazanie miłości ${ }^{37}$.

Imigrant katolik wszędzie tam, gdzie się osiedla, staje się integralną cząstką Kościoła lokalnego. Jest jego członkiem rzeczywistym, z wszystkimi wynikającymi stąd obowiązkami i prawami. Sposób, w jaki ten Kościół go przyjmuje, jest świadectwem i sprawdzianem katolickości. Jan Paweł II przypomina, że w Kościele nie ma cudzoziemców. Na mocy chrztu, bowiem chrześcijanin jest pełnoprawnym członkiem chrześcijańskiej wspólnoty tam, gdzie mieszka. Sama wspólnota winna zabiegać o jego przynależność, nie tylko po to, by określić swoje prawa, ale aby służyć ubogim. Trudna sytuacja migranta niech otwiera serca na jego przyjęcie i niech skłania do większej troski o zaspokojenie jego potrzeb. Różne przejawy braku życiowej stabilizacji, wykorzystywane przez sekty i ruchy religijne, aby sprowadzać na manowce wiarę migrantów, winny pobudzać Kościół do otoczenia ich szczególną opieką i pomocą. Przysługi, za które nierzadko muszą oni płacić wyrzeczeniem się własnej wiary, winny im być świadczone przez Kościół, który bezinteresownie troszczy się o nich i cieszy się, że może posłużyć samemu Chrystusowi. Jak Jezus jest wyrazistym obrazem miłości Ojca, tak i Kościół

\footnotetext{
$3531.07 .1992,3$.

${ }^{36} 21.08 .1991,1$.

${ }^{37} 21.08 .1991,6$.
} 
winien być obrazem czułej troskliwości Odkupiciela: musi być zatem dla wszystkich widoczne, że wspólnota, w której pojawia się imigrant, zdolna jest przyjąć go z miłością. Jan Paweł II apeluje, aby społeczność wierzących w Chrystusa nie zachowywała się nigdy jak ktoś, kto jest niezadowolony, gdyż przeszkodzono mu w jego codziennych zajęciach i planach, ale niech okazuje wobec wszystkich radość z tego, że w przybyszu spotkała i rozpoznała długo oczekiwanego Chrystusa ${ }^{38}$.

Według Kodeksu Prawa Kanonicznego duszpasterze mają „obowiązek troszczyć się o to, aby własna wspólnota kościelna świadczyła pomoc wiernym, dzięki której stan małżeński zachowa ducha chrześcijańskiego i będzie się doskonalił"39. Najistotniejszą formą tej pomocy są: przepowiadanie i katecheza, przygotowanie osobiste przyszłych małżonków, owocne sprawowanie liturgii, nieustanne wspieranie małżonków po zawarciu przez nich sakramentu małżeństwa. Jan Paweł II stwierdza, że przestrzeganie norm prawnych i gorliwa troska duszpasterska - przewidziane w Kodeksie - nabierają szczególnej wagi w środowiskach emigrantów z powodu różnorodności sytuacji, jakie się w nich spotyka ${ }^{40}$.

Swobodna integracja imigrantów, w swej ewolucji i realizacji, opiera się o samą naturę Kościoła, którą stanowi rzeczywistość wiary i miłości. Poszczególne Kościoły partykularne są wspólnotami w jednym i tym samym Ciele, w Mistycznym Ciele Chrystusa. Są Kościołem o różnych obrządkach, z odmiennymi tradycjami liturgicznymi, kulturowymi i religijnymi. Są Kościołem dostrzegającym w wiernych imigrantach osoby, którym trzeba ofiarować wszystkie środki zdolne przyczynić się do ich wzrastania w życiu wiary i miłości, pomagając im umocnić i w pełni uaktywnić ich życie kościelne, podobnie jak działo się to wówczas, kiedy znajdowali się we własnych krajach. Dlatego poszczególne Kościoły partykularne winny troszczyć się o to, aby do ich dyspozycji byli kapłani, zakonnicy i zakonnice, członkowie Instytutów Świeckich i ludzie świeccy, aby mieli właściwą liturgię, nabożeństwa w swoim własnym języku z całym szacunkiem dla ich obyczajów, do których mają prawo oraz za-

$3825.07 .1990,9$.

${ }^{39} \mathrm{CIC}, 1063$.

${ }^{40} \mathrm{~J}$ o a $\mathrm{n} n$ e s P a u 1 u s II, Ob diem in universa Ecclesia migrantibus dicatum (odtąd 15.08.1986), AAS 79 (1987), 209-216, 4. 
pewnioną pociechę Słowa Bożego także poprzez odwiedzanie ich rodzin, aby odczuli obecność Kościoła w swoim życiu codziennym, w dzielnicach, w których mieszkają, w rodzinach. W ten sposób imigranci znajdując zrozumienie i oparcie w stosunkach społecznych i w stosunkach pracy, nie będą się czuli opuszczeni zarówno w chwilach trudnych i bolesnych, jak i momentach odpręzenia i rozrywki. Trzeba zdać sobie sprawę z wymieszania języków, narodowości, chrześcijańskich tradycji, wartości kulturalnych, ze zróżnicowanej intensywności życia religijnego, z czego wynikają liczne problemy; mogą one obciążać i komplikować współpracę, porozumienie i ustalenie wspólnych perspektyw. Chociaż złożoność sytuacji wymaga wielkiej ofiary i otwartości nierzadko heroicznej, to przecież Kościoły partykularne mają świadomość i pewność, że Duch Święty potrafi wzbudzić w nich dary i charyzmaty, które zostaną w pracy duszpasterskiej z radością i zapałem przyjęte, poparte $\mathrm{i}$ rozwinięte ${ }^{41}$.

W tym kontekście Jan Paweł zwraca swoją myśl również ku zasłużonym instytutom życia konsekrowanego, gdzie się formują zakonnicy i zakonnice, którzy na mocy swego całkowitego poświęcenia się budowaniu Mistycznego Ciała Chrystusa są również gotowi do trudnej działalności duszpasterskiej, w szczególności na rzecz emigrantów najbardziej opuszczonych i potrzebujących, uchodźców, zesłańców, wygnańców, prześladowanych. Właśnie wśród tych, którzy są włączeni w owe nieustanne ruchy ludnościowe, znajdują się niekiedy klerycy, kapłani, zakonnicy, zakonnice i świeccy uświęceni i pełni oddania: w tajemnicy Opatrzności Bożej, z pomocą poszczególnych Kościolów partykularnych, w których przypadto im żyć, mogą oni stać się uprzywilejowanymi organizatorami duszpasterstwa migracyjnego. Kościoły partykularne w krajach, gdzie przeważa ludność katolicka i chrześcijańska, muszą ponadto podjąć zadanie, często bardzo pilne, wprowadzenia w życie apostolstwa pierwszej ewangelizacji misyjnej wśród wielkiej masy imigrantów, którzy nie są chrześcijanami. Może się zdarzyć, że z krajów, z których ci imigranci pochodzą, wypędzono również misjonarzy i misjonarki, znających ich język, kulturę, wartości, tradycje; właśnie dlatego ci misjonarze i misjonarki mogą stać się apostołami, gotowymi

${ }^{41} 16.07 .1985,3$. 
ofiarować do dyspozycji odpowiedzialnych pasterzy swe kompetencje i gotowość do wspólpracy ${ }^{42}$.

\subsection{Obecność migrantów w parafii}

Parafia, która zgodnie z etymologią tego słowa oznacza dom gościnnie otwarty dla przybyszów, przyjmuje wszystkich i nie dyskryminuje nikogo, bo nikt nie jest w niej obcy. Łączy stabilizację i bezpieczeństwo tych, którzy mieszkają we własnym domu, z ruchliwością lub tymczasowością sytuacji tych, którzy są w drodze. Tam, gdzie poczucie wspólnoty parafialnej jest żywe, zacierają się lub zanikają różnice między mieszkańcami danego kraju a obcokrajowcami, ponieważ przeważa świadomość wspólnej przynależności do Boga, jedynego Ojca ${ }^{43}$. Parafia jest przestrzenią, która może stać się prawdziwą szkołą spotkania z ludźmi o innych przekonaniach religijnych i wywodzących się $\mathrm{z}$ odmiennych kultur. Wspólnota parafialna, z całą swoją złożoną strukturą, może stać się szkolą gościnności, miejscem wymiany doświadczeń i darów, co Z pewnością będzie sprzyjać zgodnemu współistnieniu, zapobiegając powstawaniu napięć w relacjach $z$ imigrantami - wyznawcami innych religii ${ }^{44}$.

Każdego dnia w wielu częściach świata migranci, uchodźcy i ludzie wysiedleni zwracają się do katolickich parafii i organizacji o pomoc i są przyjmowani bez względu na przynależność kulturową czy religijną. Posługa miłosierdzia, do której chrześcijanie są powołani zawsze, nie może ograniczać się jedynie do pomocy humanitarnej. Powstają, zatem nowe sytuacje duszpasterskie, których wspólnota kościelna nie może ignorować. Jej czlonkowie winni szukać stosownych sposobności, aby dzielić się z tymi, których przyjmują, darem objawienia Boga-Miłości, „który tak umiłował świat, że Syna swego Jednorodzonego dał" (J 3, 16). Ofiarowując chleb materialny, absolutnie nie można zapominać o darze wiary, ale należy dzielić się nią przede wszystkim przez świadectwo własnego życia, zawsze w postawie głębokiego szacunku dla wszystkich. Zdaniem Jana Pawła wzajemna akceptacja i otwartość pozwalają lepiej się poznać i odkryć, że różne tradycje religijne nierzadko kryją w sobie

\footnotetext{
${ }^{42} 16.07 .1985,3$

${ }^{43} 9.11 .1997,6$.

${ }^{44} 25.07 .2001,3$.
} 
cenne ziarna prawdy. Dialog, do którego prowadzą, może wzbogacić każdego ducha otwartego na Prawdę i Dobro ${ }^{45}$.

Zjawisko migracji jest dla chrześcijan sposobnością do głębszej refleksji nad szczególnie dziś aktualnymi aspektami nowej ewangelizacji i winno pobudzać do wykorzystania wszelkich dostępnych środków, aby we wspólnotach parafialnych podjęte zostały stosowne inicjatywy apostolskie i duszpasterskie ${ }^{46}$. Obecność migrantów każe wierzącym - jako jednostkom i jako wspólnotom - zastanowić się, co powinni czynić. Wiadomo przy tym, że szczególnie ważną formą istnienia wspólnoty jest parafia. Jak przypomina Sobór Watykański II, dostarcza ona naocznego przykładu apostolstwa wspólnotowego, gromadząc w jedno wszelkie występujące w jej obrębie różnorakie właściwości i wszczepiając je w powszechność Kościoła. Parafia jest miejscem spotkania i integracji wszystkich członków wspólnoty. To dzięki niej nabiera widzialnego i społecznie określonego kształtu Boży zamysł powołania wszystkich ludzi - bez żadnego wyjątku ani dyskryminacji - do przymierza zawartego w Chrystusie ${ }^{47}$.

Misja właściwa każdej wspólnocie parafialnej oraz jej znaczenie w społeczeństwie wskazuje na doniosłą rolę, jaką parafia odgrywa w nawiązywaniu kontaktów z cudzoziemcem, w usuwaniu podziałów między ochrzczonymi wychowanymi w różnych kulturach oraz w dialogu $\mathrm{z}$ wyznawcami innych religii. Dla wspólnoty parafialnej nie jest to uboczna dzialalność zastępcza, ale powinność wpisana w jej instytucjonalne zadania. Ważną rolę w posłudze na rzecz migrantów odgrywają kapłani, powołani, aby we wspólnocie parafialnej być sługami jedności. Im to „została przez Boga udzielona laska, aby byli sługami Jezusa Chrystusa wśród ludów, pełniąc świętą posługę Ewangelii, aby ofiara ludów była przyjęta, uświęcona w Duchu Świętym". Obcując podczas codziennie sprawowanej Najświętszej Ofiary z tajemnicą Jezusa, który oddał życie, gdyż pragną1 zgromadzić w jedno rozproszone dzieci, kaplani słyszą wezwanie, aby z wciąż odnawianym zapałem służyć jedności wszystkich dzieci jedynego Ojca niebieskiego i starać się każdemu z nich zapewnić należne miejsce w braterskiej wspólnocie ${ }^{48}$.

\footnotetext{
45 25.07.2001, 4 .

46 25.07.2001, 3 .

${ }^{47} 2.02 .1999,6$.

$482.02 .1999,6$.
} 
Jan Paweł II podkreśla doniosłość chwalebnych działań podejmowanych przez liczne parafie w dzielnicach, gdzie występują takie zjawiska jak bezrobocie, ciasnota mieszkaniowa, w której zmuszeni są żyć mężczyźni i kobiety różnego pochodzenia, zaniedbanie związane z ubóstwem, brak usług socjalnych i bezpieczeństwa. Parafie są widzialnymi punktami odniesienia, latwo dostrzegalnymi i dostępnymi, są też znakiem nadziei i braterstwa nierzadko pośród jaskrawych kontrastów społecznych, napięć i wybuchów przemocy. Sluchanie tego samego Słowa Bożego, sprawowanie tej samej liturgii, wspólne obchodzenie tych samych świąt i zachowywanie tradycji religijnych - wszystko to pomaga chrześcijanom miejscowym i niedawnym imigrantom czuć się czlonkami jednego ludu. W środowisku, które jest tylko bezkształtnym tłumem anonimowych osób, parafia stanowi miejsce sprzyjające spotkaniu, wzajemnemu poznaniu i wspólnemu działaniu. Chroni przed poczuciem zagrożenia, tworząc przestrzeń zaufania, w której można się uwolnić od własnych lęków; w świecie pozbawionym zasad, z których można by czerpać wskazania i zachętę do wspólnego życia, głosi Ewangelię Chrystusa jako drogę do braterstwa i pojednania. Działając w rzeczywistości, w której silnie odczuwany jest brak bezpieczeństwa i stabilizacji, parafia może się stać prawdziwym znakiem nadziei. Skupiając najlepsze siły całej dzielnicy, pomaga mieszkańcom uwolnić się od przekonania o nieuchronności ubóstwa i podjąć skuteczne działania w celu zmiany warunków życia. Liczni członkowie wspólnot parafialnych działają też aktywnie w ramach stowarzyszen, których celem jest poprawa warunków życia ludności. Wyrażając szczere uznanie dla tych ważnych inicjatyw Jan Paweł II wzywa wspólnoty parafialne, aby $z$ odwagą i konsekwencją realizowały podjęte działania na rzecz imigrantów, a przez to przyczyniały się do kształtowania na swoim terenie poziomu życia bardziej godnego człowieka i jego duchowego powołania ${ }^{49}$.

Swobodne i czynne uczestnictwo, na równi z wiernymi urodzonymi w poszczególnych parafiach, bez ograniczeń w czasie i zastrzeżeń środowiskowych, jest dla wierzących imigrantów drogą wiodącą do ich kościelnej integracji. Chodzi tu o proces ich samodzielnego awansu, będzie, zatem rzeczą nieodzowną, żeby mieli oni możność

49 2.02.1999, 7 . 
rozumienia i oceniania, by zostali otoczeni opieką i byli wspomagani w tym wszystkim, co może być przyswojone w ramach ich życiowego doświadczenia, w postaci i stylu ich podstawowej kultury, w pluralizmie ich tożsamości. W swobodnym korzystaniu z prawa i obowiązku uczestniczenia we wspólnocie kościelnej w obrębie poszczególnych Kościołów partykularnych, poczucia się chrześcijanami i braćmi w stosunku do wszystkich, wierni imigranci winni mieć możliwość całkowitego pozostania sobą w tym, co dotyczy języka, kultury, liturgii, duchowości, poszczególnych tradycji. Jest to niezbędne dla osiągnięcia integracji kościelnej, która ubogaca Kościół Boży i jest owocem pełnego dynamiki realizmu Wcielenia Syna Bożego. W ramach emigracji każdy wysiłek zmierzający do przyspieszenia lub opóźnienia integracji lub choćby włączenia się, zwłaszcza jeśli jest on podyktowany przekonaniem o wyższości narodowej, politycznej i społecznej, może jedynie stłumić lub naruszyć ową pożądaną wielość głosów, wynikającą $\mathrm{z}$ prawa do swobody integracji, przysługującego wiernym imigrantom w każdym Kościele partykularnym, gdzie wzajemne stosunki między grupami wchodzącymi w skład tego Kościoła opierają się na gruncie szacunku dla poszczególnych kultur. Na mocy prawa do swobody integracji, specyficzny charakter kościelny, przyniesiony przez imigrantów z Kościołów partykularnych, z których pochodzą, nie staje się powodem alienacji i wyobcowania $z$ jedności wiary właśnie, dlatego że jest ona powszechna, katolicka. Jan Paweł II zauważa, że katolickość Kościoła uwidacznia się w sposób konkretny w różnorodności grup etnicznych i kultur; ta katolickość pociąga za sobą pelne otwarcie się na innych oraz gotowość do wspóluczestnictwa i współżycia w jednej wspólnocie kościelnej. „Dla pełnej katolickości, każdy naród, każda kultura ma swą własną rolę do odegrania w powszechnym planie zbawienia. Każda poszczególna tradycja, każdy Kościól miejscowy musi pilnie baczyć i otwierać się na inne Kościoły i tradycje; jeśliby pozostał zamknięty w sobie, narażałby się na niebezpieczeństwo swego wlasnego zubożenia" ${ }^{50}$.

\section{Duszpasterstwo migrantów zadaniem Kościoła}

Jan Paweł II podkreślając konieczność prowadzenia specjalistycznego duszpasterstwa migrantów zwraca uwagę na zadania

so $16.07 .1985,2$. 
duszpasterzy oraz rolę świeckich działających w ramach specjalnych struktur Kościoła mających na celu zapewnienie opieki „1udziom w drodze".

\subsection{Zadania duszpasterzy}

Jan Paweł II zauważa, że Kościól poprzez swoje duszpasterstwo stara się, aby migrantom nie brakło światła i wsparcia Ewangelii. W miarę upływu czasu poświęcał coraz więcej uwagi katolikom, którzy opuszczali swoje kraje. Zwłaszcza pod koniec XIX w. ogromne masy katolickich migrantów z Europy udawały się za ocean i często znajdowały się w sytuacjach, które zagrażały ich wierze, ponieważ brakowało kapłanów i struktur kościelnych. Nie znając miejscowego języka, migranci nie mogli korzystać z normalnej opieki duszpasterskiej w kraju, w którym się znaleźli, i często byli pozostawieni samym sobie. Migracja stanowiła, zatem zagrożenie dla wiary, co budziło niepokój wielu pasterzy, którzy w pewnych przypadkach próbowali wręcz zahamować jej dalsze postępy. Z czasem jednak stało się oczywiste, że nie można powstrzymać tego procesu. Kościól zaczął wówczas wprowadzać stosowne formy duszpasterstwa, upatrując w ruchach migracyjnych skuteczną drogę szerzenia wiary w innych krajach. Na bazie doświadczeń zgromadzonych z biegiem lat Kościół wypracowal organiczną metodę opieki duszpasterskiej nad migrantami i w 1952 r. Pius XII wydał konstytucję apostolską „Exsul familia”. W dokumencie tym stwierdzono, że należy dążyć do zapewnienia migrantom takiej samej opieki duszpasterskiej, z jakiej korzystają miejscowi chrześcijanie, dostosowując do potrzeb katolickiego migranta strukturę zwyczajnego duszpasterstwa, prowadzonego w celu zachowania i umacniania wiary ochrzczonych. Następnie także Sobór Watykański II podjął zagadnienie migracji i różnych środowisk, do których się ono odnosi: imigrantów, emigrantów, uchodźców, wygnańców i osób studiujących za granicą, należących z duszpasterskiego punktu widzenia do jednej kategorii osób, które przebywając poza granicami swojej ojczyzny nie mogą korzystać ze zwyczajnej opieki duszpasterskiej. Są oni określani jako ci, którzy ze względu na pobyt poza granicami ojczyzny czy własnego kraju potrzebują szczególnej opieki ze strony kapłana mówiącego tym samym językiem. Przedmiotem rozważań nie jest tu już zagrożenie wiary, ale bardziej istotne zagadnienie prawa emigranta do poszanowania - także przez dusz- 
pasterstwo - jego dziedzictwa kulturowego. W tej perspektywie obalona zostaje także granica wyznaczona przez konstytucję „Exsul familia”, która przewidywała opiekę duszpasterską nad migrantami do trzeciego pokolenia; uznaje się natomiast, że migranci mają prawo do opieki dopóty, dopóki istnieje jej realna potrzeba. Migranci nie są bowiem kategorią porównywalną z tymi, na jakie dzieli się społeczność parafialna - dzieci, młodzież, małżonkowie, robotnicy, pracownicy umysłowi itp. - a które są jednorodne kulturowo i językowo. Stanowią część innej społeczności, a zatem ich duszpasterstwo powinno obejmować elementy podobne jak w kraju rodzinnym, co oznacza poszanowanie ich dziedzictwa kulturowego, konieczność zapewnienia im kapłana mówiącego ich językiem oraz utworzenia trwałych struktur specjalnie dla nich przeznaczonych. Jan Paweł II stwierdza, że migrantom potrzebne jest duszpasterstwo systematyczne, indywidualne i wspólnotowe, zdolne nieść pomoc wiernym katolickim w najtrudniejszym okresie, aż do chwili ich włączenia się w Kościół lokalny, kiedy to będą w stanie korzystać ze zwyczajnej posługi kapłanów w parafiach terytorialnych ${ }^{51}$.

Zasady te zostały ujęte w obowiązującym obecnie prawodawstwie kanonicznym, które włączyło duszpasterstwo migrantów w ramy duszpasterstwa zwykłego. Niezależnie od poszczególnych przepisów Kodeks Prawa Kanonicznego i Kodeks Kanonów Kościolów Wschodnich - także w odniesieniu do duszpasterstwa migrantów charakteryzują się one tym, że czerpią inspirację eklezjologiczną z Soboru Watykańskiego II. Duszpasterstwo migrantów stało się, zatem działalnością zinstytucjonalizowaną, skierowaną ku wiernym postrzeganym nie tyle jako jednostki, ile raczej jako członkowie szczególnej wspólnoty, dla której Kościół organizuje stosowną posługę pasterską. Posługa ta jest jednak ze swej natury doraźna i tymczasowa, chociaż prawo nie określa jednoznacznie terminu, w którym ma ustać. Struktura organizacyjna tej posługi nie zastępuje, ale uzupełnia parafialne duszpasterstwo terytorialne, przez które - jak się przewiduje - prędzej czy później może zostać wchłonięta. Duszpasterstwo migrantów bowiem, choć bierze pod uwagę fakt, że dana wspólnota posługuje się odrębnym językiem i posiada własną kulturę, których nie można ignorować w codziennej pracy

${ }^{51} 2.02 .2001,4$ 
apostolskiej, nie traktuje ich zachowania i rozwoju jako własnych specyficznych celów $w^{52}$.

Papiez stwierdza, że duszpasterstwo migrantów, to dziedzina działalności Kościoła, która bardzo leży na sercu Pasterzom zdającym sobie sprawę $\mathrm{z}$ wielorakich problemów, jakie $\mathrm{w}$ niej występują, oraz z rozmaitych sytuacji zmuszających ludzi do opuszczenia własnego kraju. Czym innym jest bowiem zmiana miejsca pobytu z własnej woli, a czym innym migracja wymuszona przez przyczyny natury ideologicznej, politycznej czy ekonomicznej. Nie wolno o tym zapominać, gdy planuje się i prowadzi działalność duszpasterską dostosowaną do poszczególnych kategorii migrantów i podróżnych ${ }^{53}$.

W sytuacji niedostatku wielkiego znaczenia nabierają działania o charakterze opiekuńczym, ale nie powinno to odwracać uwagi od faktu, że także wśród nielegalnych imigrantów jest wielu chrześcijan katolików, którzy często w imię tej samej wiary szukają duszpasterzy i miejsc, gdzie mogliby się modlić, słuchać Słowa Bożego i sprawować Chrystusowe tajemnice. Obowiązkiem duszpasterzy jest wyjść naprzeciw tym oczekiwaniom ${ }^{54}$.

Migranci potrzebują szczególnej opieki duszpasterskiej ze strony wspólnoty kościelnej, wrażliwej nie tylko na ich osobiste cierpienia, ale także na negatywne skutki trudnych warunków bytowych, które mogą się odbić zwlaszcza na życiu ich rodzin. Zjawisko migracji wywiera bowiem głęboki wpływ na wspólnoty rodzinne ${ }^{55}$. Dla wspólnot kościelnych dodatkowym powodem po temu, by gościnnie przyjmować migrantów i poczuwać się do obowiązku otoczenia ich duchową opieką, powinno być wspólne z nimi wyznanie wiary. Niech jednak pamiętają, że nie można skutecznie sprawować opieki duszpasterskiej nad migrantami, jeżeli nie uwzględnia się należycie ich duchowego dziedzictwa i kultury. Problemy duszpasterskie w tej dziedzinie należy, zatem rozpatrywać w świetle zasad oceny i rozeznania, które regulują stosunki między jedną wiarą a różnymi kulturami. Jan Paweł II podkreśla, ze stanie się to łatwiejsze, jeśli duszpasterstwo migrantów będzie umiało docenić wartość wkładu

\footnotetext{
$52.02 .2001,5$

${ }^{53} 2.02 .2001,1$.

${ }^{54} 25.07 .1995,5$.

55 31.07.1992, 1.
} 
wnoszonego przez różne społeczności etniczne i jeśli uniknie się niebezpieczeństwa tworzenia duszpasterstwa „marginesu” dla ludzi znajdujących się „na marginesie” społeczeństwa ${ }^{56}$.

Działanie na rzecz społecznej promocji migrantów stanowi tylko jeden ze składników pracy duszpasterskiej. Nie mniej istotna jest ich formacja chrześcijańska poprzez głoszenie prawd wiary i zwiastowanie rzeczywistości ostatecznych, ku którym zwraca się chrześcijańska nadzieja. Imigrant ma do tego prawo, obowiązkiem zaśs Kościoła jest wychodzenie mu naprzeciw także w tej dziedzinie. Nie chodzi tu o zwykłe duszpasterstwo, jakie prowadzi się pośród ogółu wiernych, ale o duszpasterstwo szczególnego rodzaju, przystosowane do sytuacji człowieka oderwanego od swych korzeni, sytuacji typowej dla migranta, który musi żyć z dala od macierzystej spoleczności; winno ono brać pod uwagę jego język, a przede wszystkim kulturę, w której wyraża on swoją wiarę; duszpasterstwo to, winno być rozbudowane odpowiednio do potrzeb migrantów i równie skuteczne jak duszpasterstwo prowadzone wśród wiernych diecezji ${ }^{57}$. Aby odpowiedzieć na potrzeby duszpasterskie, Kościól ma do dyspozycji różne środki. Z analizy porównawczej sytuacji w krajach mających długą tradycję przyjmowania migrantów wynika, że parafie personalne skuteczniej niż inne inicjatywy chronity wiarę migrantów przed licznymi niebezpieczeństwami, na jakie byli narażeni. Ze swej strony powstałe $z$ czasem społeczności etniczne przyczyniły się bardzo do odnowy i umocnienia Kościołów, które je przyjęly. Papież, zatem formułuje stwierdzenie, że umiejętnie prowadzone duszpasterstwo migrantów pozwala obiektywnie zweryfikować zdolność duszpasterzy i danego Kościola lokalnego do konsekwentnej realizacji w życiu nauki Chrystusa ${ }^{58}$.

\subsection{Rola świeckich w apostolstwie na rzecz migrantów}

Jan Paweł II mówiąc o misji świeckich zwraca się także do duszpasterzy działających na polu emigracji i podkreśla, że bez ich pracy nie mogłyby powstawać grupy zaangażowanego laikatu. Na kapłanach, więc spoczywa bezpośrednia odpowiedzialność za aktywność świeckich. Papież podkreśla znaczenie nastawienia się na

\footnotetext{
$5631.07 .1992,3$.

${ }^{57} 25.07 .1990,10$.

$5825.07 .1990,11$.
} 
duszpasterstwo świeckich dorosłych. Nie może to oczywiście oznaczać zaniedbywania duszpasterstwa dzieci, młodzieży, czy innych kategorii osób. Chodzi tu o docieranie do nich inną drogą. Wybór ludzi dorosłych podyktowany jest przede wszystkim tym, że katecheza nie polega tylko na nauczaniu, lecz także na wspólnym przeżywaniu - poprzez przemianę sposobu myślenia - wszystkich aplikacji wiary do rzeczywistości egzystencjalnej; podyktowany jest także i tym, że dorośli, dając konkretny przykład przeżywania podstawowej dla chrześcijanina relacji między wiarą i życiem, sami stają się katechetami własnych rodzin. W ten sposób rodzina staje się prawdziwym „kościołem domowym”, który naucza, daje świadectwo i przekazuje życie nie tylko w sensie fizycznym, ale również duchowym $^{59}$. Tak, więc duszpasterstwo musi mieć zawsze na uwadze wymienione wyżej wartości podstawowe i popierać je poprzez określone metody interwencji ${ }^{60}$. Duszpasterstwo rodzin - będące formacją świeckich apostołów migracji - nie może być takie samo w każdym czasie i miejscu. Różnorakie formy tego duszpasterstwa muszą uwzględniać sytuację emigranta, środowisko, z którego się wywodzi, oraz to, w którym żyje, jak również to, jakie ma przed sobą konkretne perspektywy ${ }^{61}$.

\section{Ochrona praw migrantów}

Jan Paweł II występując w orędziach w obronie praw należnych migrantom szczególnie zwraca uwage na te, które we współczesnym świecie są najbardziej zagrożone. Papież przypomina o: prawie do nieemigrowania; prawie człowieka do emigrowania; prawie migranta do zachowania własnej tożsamości; prawie do zawarcia małżeństwa; prawie do życia we własnej rodzinie; prawach rodziny.

\subsection{Prawo do nieemigrowania}

Ojciec Święty zwraca uwagę na fakt, że - mówiąc o migrantach - trzeba brać pod uwagę warunki życia w krajach ich pochodzenia. W krajach tych panuje zazwyczaj wielkie ubóstwo, które często pogłębia się pod wpływem zadłużenia zagranicznego. Papież odwołując się do listu apostolskiego „Tertio millennio adveniente” przy-

\footnotetext{
59 $15.08 .1986,5$

${ }^{60} 15.08 .1986,4$.

${ }^{61} 15.08 .1986,6$.
} 
pomina, że „chrześcijanie, nawiązując do zasad zapisanych w Księdze Kapłańskiej (25, 8-28), powinni stać się rzecznikami wszystkich ubogich świata, proponując, aby Wielki Jubileusz Roku 2000 stal się, między innymi, sposobnością do przemyślenia sprawy redukcji, jeśli nie całkowitej likwidacji zadłużenia międzynarodowego, które ciąży na losach wielu narodów" (nr 51). Jest to jeden z aspektów migracji, które najściślej łączą je z Jubileuszem, nie tylko dlatego że ze wspomnianych krajów biorą początek najsilniejsze ruchy migracyjne, ale przede wszystkim dlatego że Jubileusz, proponując określoną wizję podziału dóbr ziemi, która potępia zasadę wyłącznej własności (por. Kpl 25, 23), skłania człowieka wierzącego do otwarcia się na ubogich i cudzoziemców. W dawnych epokach narastający kontrast między bogatymi a ubogimi, uniemożliwiający normalne współistnienie społeczne, stwarzał co jakiśs czas konieczność przywracania pierwotnej równowagi majątkowej, co pozwalało na dalszy uporządkowany rozwój społeczny. Znosząc w ten sposób zobowiązania ciążące na ludziach, którzy popadli w niewolę $\mathrm{z}$ powodu zadłużenia, ustanawiano od nowa pewną formę równości. Biblijne przepisy dotyczące jubileuszu to jedna z wielu form korygowania nierównowagi społecznej, wytworzonej przez podstępne mechanizmy, których ofiarą padają ludzie zmuszeni do zaciągnięcia dlugów, aby przeżyć. Zjawisko to, które wówczas dotyczyło stosunków między mieszkańcami jednego kraju, nabiera wymiarów bardziej dramatycznych w związku z obecną globalizacją ekonomii i handlu, zachodzącą w relacjach między państwami i regionami świata. Aby dysproporcje między krajami bogatymi a ubogimi nie stały się nieodwracalne, co miałoby tragiczne konsekwencje dla całej ludzkości, trzeba także dzisiaj znaleźć konkretne i skuteczne formy realizacji biblijnego nakazu, które pozwolą dokonać niezbędnej rewizji zadłużenia krajów ubogich wobec krajów bogatych ${ }^{62}$.

Jan Paweł II wyraża pragnienie, aby Jubileusz stał się, zgodnie z postulatami zgłaszanymi z wielu stron, sposobnością do znalezienia stosownych rozwiązań i do stworzenia krajom ubogim nowych warunków godnego i uporządkowanego rozwoju. Współczesny świat, w którym tak wiele jest przejawów niesprawiedliwości i ego-

${ }^{62} 2.02 .1999,8$. 
izmu, okazuje jednocześnie zaskakującą gotowość do obrony słabych i ubogich. W ostatnich latach można zauważyć, że wzrasta wśród chrześcijan solidarność, która pobudza do bardziej wyrazistego świadczenia o Ewangelii miłości. Umiłowanie ubogich i służba im nie powinny jednak skłaniać do myślenia, że wiara jest mniej potrzebna, ani wprowadzać sztucznego podziału w jedynym i nierozłącznym przykazaniu Bożym, które nakazuje miłować jednocześnie Boga i bliźniego ${ }^{63}$. Kiedy zrozumienie tego problemu utrudniają przesądy i ksenofobia, Kościół musi wystąpić jako rzecznik braterstwa, wspierając swoje nauczanie gestami, które dają świadectwo prymatu miłości. Solidarność oznacza przyjęcie odpowiedzialności za kogoś, kto znajduje się w trudnej sytuacji. Dla chrześcijanina imigrant nie jest jedynie człowiekiem, którego należy szanować zgodnie z przepisami ustalonymi przez prawo, ale osobą, której obecność stanowi dla niego wyzwanie i za której potrzeby jest on odpowiedzialny. „Gdzie jest brat twój?” (Rdz 4, 9). Odpowiedź na to pytanie nie powinna zamykać się w granicach wyznaczonych przez prawo, ale kierować się logiką solidarności ${ }^{64}$.

Jan Paweł II podkreśla, że należy się troszczyć o zabezpieczenie przede wszystkim prawa do nieemigrowania, to znaczy do godnego życia w pokoju we własnej ojczyźnie. Poprzez rozważną politykę władz lokalnych i ogólnokrajowych, handel oparty na relacjach bardziej partnerskich oraz solidarną współpracę międzynarodową należy zadbać o to, aby każdy kraj mógł zapewnić swoim mieszkańcom nie tylko wolność wyrażania poglądów i swobodę poruszania się, ale także możliwość zaspokojenia podstawowych potrzeb, takich jak wyżywienie, zdrowie, praca, mieszkanie, wykształcenie. Niemożliwość zaspokojenia owych potrzeb zmusza wielu ludzi do emigracji. Istnieje, zatem także prawo do emigracji, u którego podstaw leży zasada powszechnego przeznaczenia dóbr tego świata ${ }^{65}$.

\subsection{Prawo czlowieka do migracji}

Ojciec Święty przypomina, iż człowiek posiada prawo do migracji. Kościół uznaje, że każdy człowiek posiada to prawo w podwój-

${ }^{63} 21.08 .1996,3$.

${ }^{64} 25.07 .1995,5$.

${ }^{65} \mathrm{~J}$ o a $\mathrm{n} \mathrm{n}$ e s $\mathrm{P}$ a u 1 u s II, Ob diem migratoribus et itinerantibus dicatum (15.12.2003), AAS 96 (2004), 427-430, 3. 
nym aspekcie: mianowicie ma możność opuścić własny kraj oraz udać się do innego w poszukiwaniu lepszych warunków życia. Rzecz jasna, korzystanie $z$ tego prawa musi być odpowiednio regulowane, ponieważ jego nieuporządkowane stosowanie przynosiłoby szkodę i zagrażałoby dobru wspólnemu społeczności, które przyjmują migrantów. Papież zauważa, że przeplatanie się wielu różnych interesów sprawia, iż obok ustaw poszczególnych krajów potrzebne są normy międzynarodowe określające prawa wszystkich zainteresowanych, tak aby można było zapobiec decyzjom jednostronnym, na niekorzyść słabszych. Jan Paweł II podejmując ten temat przypomina, że chociaż prawdą jest, iż kraje wysoko rozwinięte nie zawsze są zdolne wchłonąć wszystkich emigrantów, jednak określając granicę tej zdolności nie mogą kierować się wyłącznie pragnieniem ochrony własnego dobrobytu, zapominając o rzeczywistych potrzebach tych, którym dramatyczne okoliczności każą szukać gościny gdzie indziej ${ }^{66}$.

Jan Paweł II przypomina, że prawo do emigrowania łączy się ściśle z chrześcijańskim obowiązkiem udzielania gościnności. Kościól - jako Matka i Nauczycielka - zabiega o to, aby godność każdego człowieka była szanowana, aby imigrant był przyjmowany jako brat oraz by cała ludzkość tworzyła jedną rodzinę, umiejącą rozumnie docenić różne kultury, które ją wspóltworzą. W Jezusie Bóg przyszedł, aby poprosić ludzi o gościnę. Wskazuje przez to, że cnotą typową dla osoby wierzącej jest gotowość przyjęcia z miłością drugiego czlowieka. Jezus zechciał narodzić się w rodzinie, która nie znalazła miejsca w betlejemskiej gospodzie (por. Łk 2, 7), i przeżył doświadczenie ucieczki do Egiptu (por. Mt 2, 14). Jezus, który „nie miał miejsca, gdzie by głowę mógł oprzeć" (Mt 8, 20), prosił o gościnę napotykanych ludzi. Do Zacheusza powiedzial: „dziś muszę się zatrzymać w twoim domu" ( Lk 19,5). Utożsamia się nawet z cudzoziemcem potrzebującym schronienia: „byłem przybyszem, a przyjęliście Mnie” (Mt 25, 35). Gdy wysyłał swoich uczniów na misję uznal, że gościnność, jaka zostanie im okazana, będzie dotyczyć Jego osobiście: „Kto was przyjmuje, Mnie przyjmuje; a kto Mnie przyjmuje, przyjmuje Tego, który Mnie posłał" (Mt 10, 40). Obowiązek udzielenia gościnności szczególnie mocno akcentuje

${ }^{66} 2.02 .2001,3$ 
Jan Pawel II w Roku Jubileuszowym oraz w kontekście narastających wszędzie przemieszczeń ludności. Papież stawia pytanie: ,jakże mogliby ochrzczeni twierdzić, że przyjmują Chrystusa, jeżeli zamykają drzwi przed cudzoziemcem, który do nich przychodzi?". Syn Boży stał się człowiekiem, aby dotrzeć do wszystkich, a szczególnie upodobał sobie najmniejszych, odrzuconych, obcych. Gdy rozpoczynał swoją misję w Nazarecie, przedstawił się jako Mesjasz, który głosi Dobrą Nowinę ubogim, przynosi wolność więźniom, przywraca wzrok ślepcom. Przychodzi, aby ogłosić ,rok łaski od Pana" (Lk 4, 18), który jest wyzwoleniem i początkiem nowej epoki braterstwa i solidarności. To działanie Chrystusa, zawsze obecne w Kościele, ma prowadzić do tego, aby wszyscy, którzy czują się obcy, włączyli się w nową braterską wspólnotę; uczniowie zaś są powołani, aby stawać się sługami tego miłosierdzia, ażeby nikt się nie zagubil (por. J 6, 39) ${ }^{67}$.

\subsection{Prawo migranta do tożsamości}

Jan Paweł II zauważa, że obecne czasy charakteryzują głębokie przemiany w sposobie życia i myślenia, które obok elementów pozytywnych niosą też z sobą nieuchronnie zjawiska dwuznaczne. Poczucie tymczasowości skłania na przykład do wybierania tego, co nowe nieraz ze szkodą dla stabilnej i wyraźnej hierarchii wartości; zarazem umysł ludzki staje się bardziej chłonny i otwarty, wrażliwy i skłonny do dialogu. Taki klimat może pobudzić człowieka do pogłębienia własnych przekonań, ale także do ulegania łatwemu relatywizmowi. Zmiana miejsca pobytu wiąże się zawsze $\mathrm{z}$ wykorzenieniem z rodzimego środowiska, co często pociąga za sobą doświadczenie dotkliwej samotności i ryzyko zagubienia się w anonimowym tłumie. Te sytuacje mogą prowadzić do odrzucenia nowego kontekstu, ale także do jego bezkrytycznej akceptacji, która oznacza bunt wobec dotychczasowych doświadczeń. Czasem występuje też skłonność do biernego przystosowania, która łatwo może stać się źródłem alienacji kulturowej i społecznej. Przemieszczanie się ludzi stwarza liczne możliwości otwarcia się na innych, spotkania, tworzenia związków, ale trzeba też dostrzegać, że rodzi ono czasem

${ }^{67} \mathrm{G}$ i o v a $\mathrm{n} \mathrm{n}$ i $\mathrm{P}$ a o 1 o II, La figura dell esule dà al giubileo un significato concreto: per $i$ credenti esso diventa richiamo al cambiamento di vita. Messaggio per la giornata mondiale del migrante (21.11.1999), „Migranti-press” 50, 6-8, 5. 
wrogość wobec jednostek i społeczności, która jest wytworem ciasnej mentalności, występującej w społeczeństwach nękanych przez różne napięcia i lęki ${ }^{68}$. Papież zauważa, że zróżnicowane warunki życia przybierają - również we wspólnocie kościelnej - ksztalt trudnych powikłań; jedynie poszanowanie praw i wypelnianie obowiązków może być pomocne w ich rozwiązaniu ${ }^{69}$.

Kościół stara się zawsze pamiętać o tych poważnych problemach w swojej pracy duszpasterskiej. Celem głoszenia Ewangelii jest integralne zbawienie człowieka, jego prawdziwe i skuteczne wyzwolenie poprzez zapewnienie mu warunków życia licujących z jego godnością. Wiedza o człowieku - jaką Kościól zyskał w Chrystusie każe mu głosić podstawowe prawa ludzkie i otwarcie występować w ich obronie, gdy są łamane. Dlatego Kościół niestrudzenie przypomina o godności człowieka i broni jej, ukazując niezbywalne prawa, jakie $z$ niej wyplywają. Trzeba oczywiście połączyć zasadę poszanowania odmienności kulturowych z ochroną wspólnych wartości, z których nie wolno rezygnować, gdyż ich fundamentem są uniwersalne prawa człowieka ${ }^{70}$. Należy do nich zwłaszcza prawo do ojczyzny, do swobodnego zamieszkiwania we własnym kraju, do życia wspólnie z rodziną, do posiadania dóbr niezbędnych do godziwego życia, do zachowania i rozwijania własnego dziedzictwa etnicznego, kulturowego i językowego, do publicznego wyznawania swojej religii, a wreszcie do tego, aby w każdych okolicznościach być szanowanym i traktowanym w sposób odpowiadający godności ludzkiej isto$t^{71}$. Prawa te znajdują konkretne zastosowanie w koncepcji powszechnego dobra wspólnego. Ogarnia ona calą rodzinę narodów, przekraczając granice egoistycznych nacjonalizmów.

\subsection{Prawo do zawarcia małżeństwa}

Papież wieloaspektowo porusza kwestie dotyczące prawa do zawierania małżeństwa. Zauważa, że świadome i roztropne zawarcie małżeństwa mieszanego wymaga znajomości istotnych elementów określających tożsamość obydwu Kościolów czy Wspólnot kościelnych - tego, co je łączy i tego, co je różni. Pokonawszy ewentualne

\footnotetext{
68 2.02.2001,2.

69 16.07.1985, 2 .

$7024.11 .2004,2$.

${ }^{71} 2.02 .2001,3$.
} 
uprzedzenia, każde z małżonków wnosi w małżeństwo własną wrażliwość osobową i religijną, aby przez to wzbogacić wspólne życie i przyczynić się do wychowania dzieci, w czym zawsze należy inspirować się wiarą. Małżonek katolicki winien wypelniać te obowiązki zgodnie z zasadami wynikającymi z jego przynależności kościelnej $^{72}$. Jan Paweł II zauważa, że można dziś odnotować znaczny wzrost liczby małżeństw zawieranych między katolikami a osobami wyznającymi religie niechrześcijańskie. Szacunek należny tym tradycjom religijnym nie może przesłaniać faktu, że konieczne jest, aby dla tych małzeństw Konferencje Episkopatów oraz poszczególni biskupi podjęli odpowiednie środki pastoralne, mające na celu zapewnienie ochrony wiary małzonka katolickiego i zabezpieczenie mu wolności praktykowania, zwłaszcza w tym, co odnosi się do obowiązku uczynienia wszystkiego, co jest w jego mocy, aby dzieci otrzymały chrzest i wychowanie katolickie. Małżonek katolicki winien ponadto być wspierany wszelkimi sposobami w jego zadaniu świadczenia w łonie rodziny poprzez wiarę i życie katolickie. Tá konieczność jest tym pilniejsza, im większe jest prawdopodobieństwo, że partner katolicki będzie musiał udać się za partnerem niechrześcijańskim do kraju, w którym religia panująca wpływa odczuwalnie na życie całego społeczeństwa i w praktyce ogranicza do minimum przestrzeń wolności innych wyznań ${ }^{73}$.

Stosowna katecheza dla narzeczonych reprezentujących odmienne religie nie może, więc ograniczać się tylko do garści przedmałżeńskich pouczeń, lecz musi zmierzać do kształtowania osób o wyraźnej świadomości religijnej, aktywnych w życiu społeczności, świadomych własnych motywacji wiary i nadziei, a także motywów sumienia i wiary swych bliźnich; osób zaangażowanych w służbę ubogim i całej wspólnocie ${ }^{74}$.

4.5. Prawo migrantów do życia we własnej rodzinie

Jan Paweł wyraża zadowolenie z faktu, że w większości krajów uznaje się prawo migranta do życia w gronie własnej rodziny oraz ze wiele instytucji międzynarodowych potwierdziło to prawo, podkreślając jego aktualność i znaczenie. Stwierdza jednak, że

\footnotetext{
$7231.07 .1992,4$

$7331.07 .1992,5$.

${ }^{74} 15.08 .1986,5$.
} 
w sprzeczności z uznaniem tego prawa pozostaje istnienie różnego rodzaju przeszkód, które czasem nie pozwalają rzeczywiście z niego korzystać. Uwzględniając szczególne potrzeby rodzin imigrantów państwo powinno starać się, aby nie brakowalo im tego, co normalnie zapewnia ono własnym obywatelom. Państwo ma zwłaszcza za zadanie bronić ich przed wszelkimi próbami marginalizacji i przejawami rasizmu, kształtując kulturę opartą na szczerej i czynnej solidarności. W tym celu powinno przygotować wszelkie skuteczne i konkretne środki służące gościnnemu przyjęciu imigrantów, a także instytucje społeczne, które również mogą im stworzyć warunki spokojnego życia i rozwoju odpowiadającego ich ludzkiej godności $^{75}$. Papież przypomina nauczanie Soboru Watykańskiego II, że jeśli chodzi o robotników obcej narodowości czy też pochodzących $\mathrm{z}$ innego kraju, którzy przecież swoją pracą przyczyniają się do rozwoju gospodarczego ludności miejscowej lub danego kraju, należy w stosunku do nich unikać wszelkiej dyskryminacji w zakresie pracy i płacy. Ponadto wszyscy, a przede wszystkim władze państwowe, niech nie uważają ich tylko za zwyczajne narzędzie produkcji, lecz za osoby, i niech im okazują pomoc w sprowadzeniu do siebie rodziny. W takiej perspektywie należy podejmować problemy związane na różne sposoby ze zjawiskiem migracji, takie zwłaszcza jak kwestia mieszkania, pracy i bezpieczeństwa, a także problemy wynikające $z$ odmienności języka, kultury i wykształcenia ${ }^{76}$.

\subsection{Ochrona praw rodziny}

Kościół, „sakrament zbawienia” dla wszystkich ludzi broni podstawowych wartości rodziny niezależnie od wzorca kulturowego, na jakim jest ona oparta, piętnuje także to wszystko, co się jej sprzeciwia. Kościół domaga się dla niej swobody ruchów i decyzji, a także podstawowego, przysługującego rodzinie prawa do wychowania potomstwa. W związku z tym Jan Pawel II stwierdza, że w razie konfliktu pomiędzy społeczeństwem a rodziną przeważyć musi w zasadzie interes tej ostatniej. W bardzo rozpowszechnionych, niestety, wypadkach podziałów w łonie samych rodzin należy, z jednej strony, łagodzić zatargi, zwłaszcza drogą pobudzania wspólnot kościelnych do aktywnego zajmowania się powstającymi na tym tle

75 31.07.1992, 1 .

$7631.07 .1992,2$. 
problemami, z drugiej zaś, nie wolno zaniedbywać niczego, co mogłoby pomóc w przezwyciężaniu wszelkich sytuacji tymczasowości. Należy zawsze zabiegać o pelną jedność rodzin i o to, aby rodzina emigranta zawsze mogła znaleźć dla siebie miejsce, jakiego potrzebuje i jakie $z$ racji jej godności słusznie się jej należy na równi z rodzinami miejscowymi. „Rodziny emigrantów... powinny znaleźć wszędzie w Kościele swą ojczyznę... O ile to możliwe, niech mają zapewnioną posługę kapłanów własnego obrządku, kultury i języka”. Wspólnoty kościelne, nawiązując kontakt $z$ rodzinami emigrantów w miejscach ich zamieszkania, winny być gotowe do niesienia im w razie potrzeby pomocy, a jednocześnie zapraszać do uczestnictwa w życiu parafii. Powstawanie nowych rodzin jest momentem decydującym dla przyszłości zainteresowanych młodych oraz dla pomyślności społeczności cywilnej i kościelnej; jest to zagadnienie stojące poniekąd w centrum zainteresowań młodzieży. Doświadczenia duszpasterstwa emigracji dostarczają obficie dowodów i podkreślają z mocą, że przyszlych małżonków należy informować zarówno w zakresie różnorakich trudności mogących wpływać na ich związek, jak też - i przede wszystkim - o czynnikach pozytywnych, mogących ubogacić tenże związek, którego trwałość wymaga zasadniczej zgodności poglądów obu stron, polączonej z gotowością do możliwie najpelniejszego dostosowywania się do siebie nawzajem. W tym punkcie wskazania duszpasterskie muszą być jasne, rzeczowe i logiczne. Winny one uwzględniać fakt, że największe przeszkody dla zawierających małżeństwo tworzą różnice kultur, wykształcenia, religii, osobistych przekonań ${ }^{77}$.

Twórcza postawa i zapał misjonarzy oraz osób działających pod kierunkiem duszpasterzy mają tu szerokie pole, zawsze jednak w ramach norm, które Kościół ustalił w Kodeksie Prawa Kanonicznego oraz poprzez różne zalecenia Konferencji Episkopatów i poszczególnych biskupów. Bowiem przy całym możliwym zróżnicowaniu metod i propozycji nigdy nie wolno tracić sprzed oczu podstawowego wspólnego kierunku, jakim jest urzeczywistnianie planu Boga: aby mężczyzna i kobieta stanowili jedno ciało (por. Mt 19, 6) poprzez złączenie się węzłem małżeńskim i by tworzyli symboliczny obraz wielkiej tajemnicy wzajemnego stosunku Chrystusa

\footnotetext{
${ }^{77} 15.08 .1986,4$
} 
i Kościoła (por. Ef 5, 32). Narzeczeni, pary małżeńskie, rodziny winny być wychowywane $\mathrm{w}$ duchu solidarności wzajemnej w obrębie wspólnoty kościelnej oraz wobec całego społeczeństwa. Aczkolwiek podstawą małżeństwa i rodziny jest wolny, osobisty wybór, to jednak zawsze stanowią one fakt społeczny i cząstkę wspólnoty kościelnej ${ }^{78}$.

\section{Zakończenie}

Zjawisko migracji ukazane przez Jana Pawła II w orędziach na Światowy Dzień Migranta jest złożone i wielowymiarowe, w którym występują zarówno czynniki postępu, jak i powikłania i niebezpieczeństwa zarówno w życiu poszczególnych jednostek, jak i całych społeczeństw. Jan Paweł II, Biskup Rzymski interesował się tym zjawiskiem, aby właściwie wypełniać swoje powołanie wśród ludów ziemi. W ten sposób kontynuował troskę Kościoła o migrantów, która ma bardzo bogatą historię zarówno w zakresie działalności pastoralnej, jak i prawodawczej, bowiem te dwie dziedziny życia Kościoła na wzajem się przenikają i uzupełniają. W orędziach na Światowy Dzień Migranta - w poszczególnych latach swojego pontyfikatu - Jan Pawel II akcentowal aktualne problemy związane ze zjawiskiem migracji.

Pośród licznych dylematów, jakie rodzi migracja dla poszczególnych dziedzin życia ludzkiego i społecznego Papież akcentował kwestie przynależności migrantów do Kościoła powszechnego. Wiara i chrzest w imię Trójcy Świętej, łączność z Biskupem Rzymu i Kolegium Biskupów oraz instytucjami Stolicy Apostolskiej są czynnikami jedności migrantów z Kościołem i sprawiają, że Kościól jest obecnym w środowiskach wielokulturowych i wieloreligijnych.

W orędziach Jana Pawła II obecność migrantów w Kościele urzeczywistnia się w Kościele partykularnym, który jako diecezja i wspólnota parafialna troszczy się przede wszystkim o zaspokojenie duchowych potrzeb migrantów, co wplywa na styl prowadzonego duszpasterstwa.

Jan Paweł II występując w obronie praw migrantów akcentował: prawo człowieka zarówno do nieemigrowania, jak i do migrowania oraz podkreślał, że emigrant ma prawo do zachowania własnej toż-

${ }^{78} 15.08 .1986,6$. 
samości. Orędzia na Światowy Dzień Migranta są znaczącym głosem w obronie prawa migrantów do: zawarcia małżeństwa, życia we własnej rodzinie oraz przestrzegania praw rodziny.

Podsumowując należy stwierdzić, że Jana Pawła II w orędziach dużo miejsca poświęcił kanonicznym problemom współczesnej migracji. Wiele z przedstawionych problemów migracji znalazło swoje rozwiązanie w prawie powszechnym i specjalnym Kościoła, szczególnie w opublikowanej przez Papieską Radę Duszpasterstwa Migrantów i Podróżnych instrukcji „Erga migrantes caritas Christi”. Zakładając dynamikę prawa wydaje się, że kwestie przedstawione w orędziach w dalszym ciągu będą podejmowane przez kościelnego Prawodawcę.

\section{Messages of the Holy Father John Paul II for the World Migration Days. The canonical issues}

The migration issues make an extensive and multifaceted subject in John Paul's teaching. Expressions of these are, among other things, his Messages for the World Migration Day. In twenty-six years of his pontificate the Pope pointed out the problems of modern migration, which concern individual aspects of life of the Church and of the World. In his Messages the Pope also undertakes canonical issues of migration and shows us the ways to solve them.

The Pope's leading item is a statement that all migrants need special concern on account of their specific situation. It is a duty of the Church to provide a pastoral care for them.

Pope John Paul II always defends human rights especially a human right to emigrate and he supports migrants' right to maintain their own identity. The Pope pays special attention to their rights to form the family and to maintain the family rights. 